\title{
Spheroidizing Behavior and Spheroidizing Kinetics of W-phase During Solid-Solution Treatment in Mg-Zn-Y-Mn-(B) Alloys
}

\author{
Kai Yang $^{1,2} \cdot$ Jin-Shan Zhang ${ }^{1,2} \cdot$ Xi-Mei Zong ${ }^{1,2} \cdot$ Wei Liu ${ }^{1,2} \cdot$ Chun-Xiang Xu ${ }^{1,2}$
}

Received: 10 August 2016/Revised: 11 October 2016/Published online: 3 December 2016

(C) The Chinese Society for Metals and Springer-Verlag Berlin Heidelberg 2016

\begin{abstract}
The spheroidizing mechanism of W-phase in the $\mathrm{Mg}-\mathrm{Zn}-\mathrm{Y}-\mathrm{Mn}-(\mathrm{B})$ alloys during solid-solution treatment was investigated by using kinetic methodologies. The microstructure and mechanical properties of heat-treated $\mathrm{Mg}_{94} \mathrm{Zn}_{2.5-}$ $\mathrm{Y}_{2.5} \mathrm{Mn}_{1}$ alloy containing $0.003 \mathrm{wt} \% \mathrm{~B}$ were compared with heat-treated $\mathrm{Mg}_{94} \mathrm{Zn}_{2.5} \mathrm{Y}_{2.5} \mathrm{Mn}_{1}$ alloy. The heat-treated $\mathrm{Mg}_{94} \mathrm{Zn}_{2.5} \mathrm{Y}_{2.5} \mathrm{Mn}_{1}$ alloy with $0.003 \mathrm{wt} \% \mathrm{~B}$ contained fine and uniform $\mathrm{W}$-phase particles, which exhibited optimal mechanical performance. The ultimate tensile strength, yield strength and elongation were 287.7, 125.5 MPa and 21.1\%, respectively.
\end{abstract}

KEY WORDS: Magnesium alloys; W-phase; Spheroidizing; Kinetics; Microstructure; Mechanical properties

\section{Introduction}

In recent years, ternary $\mathrm{Mg}-\mathrm{Zn}-\mathrm{Y}$ system alloys have attracted considerable attention due to their excellent mechanical properties and unique microstructures [1-4]. Generally, it is found that there are three kinds of ternary phases in $\mathrm{Mg}-\mathrm{Zn}-\mathrm{Y}$ system: icosahedral quasicrystal structure $\mathrm{Mg}_{3} \mathrm{Zn}_{6} \mathrm{Y}$ (I-phase), eutectic structure $\mathrm{Mg}_{3} \mathrm{Zn}_{3} \mathrm{Y}_{2}$ (W-phase) and 18R long-period stacking ordered (LPSO) structure $\mathrm{Mg}_{12} \mathrm{YZn}$ (X-phase) [5, 6]. As recently reported,

Available online at http://link.springer.com/journal/40195

Jin-Shan Zhang

jinshansx@tom.com

1 College of Materials Science and Engineering, Taiyuan University of Technology, Taiyuan 030024, China

2 Shanxi Key Laboratory of Advanced Magnesium-based Materials, Taiyuan 030024, China the $\mathrm{W}$-phase in network state is a brittle phase, where the crack can easily occur during the tensile process [7]. The alloying [8] and solid-solution treatment $[9,10]$ can be adopted to optimize the morphology and distribution of eutectic phase, improving the strength and plasticity of the materials. Up to now, there is barely available information reported on the spheroidizing behavior of $\mathrm{W}$-phase. And the effect of globular W-phase on the mechanical properties of $\mathrm{Mg}-\mathrm{Zn}-\mathrm{Y}$ system alloys is still unclear. Therefore, it is necessary to investigate the spheroidizing mechanism of $\mathrm{W}$-phase in $\mathrm{Mg}-\mathrm{Zn}-\mathrm{Y}$ alloy system and, especially, its influence on the mechanical properties. As reported in our previous work, a small amount of $\mathrm{B}$ inhibited the formation of W-phase in $\mathrm{Mg}_{94} \mathrm{Zn}_{2.5} \mathrm{Y}_{2.5} \mathrm{Mn}_{1}$ alloy, which can improve the alloy's performances [11]. In this study, the research on the spheroidizing behavior of $\mathrm{W}$-phase in the $\mathrm{Mg}_{94} \mathrm{Zn}_{2.5} \mathrm{Y}_{2.5} \mathrm{Mn}_{1}$ alloys containing different amounts ( 0.000 and $0.003 \mathrm{wt} \%)$ of $\mathrm{B}$ was carried out using the solid-solution treatment method. Spheroidizing kinetics of $\mathrm{W}$-phase during the solid-solution treatment process was analyzed. Besides, the microstructure and mechanical properties of heat-treated $\mathrm{Mg}_{94} \mathrm{Zn}_{2.5} \mathrm{Y}_{2.5} \mathrm{Mn}_{1}$ alloy containing $0.003 \mathrm{wt} \% \mathrm{~B}$ were compared with heat-treated $\mathrm{Mg}_{94} \mathrm{Zn}_{2.5} \mathrm{Y}_{2.5} \mathrm{Mn}_{1}$ alloy. 


\section{Experimental}

The $\mathrm{Mg}-\mathrm{Zn}-\mathrm{Y}-\mathrm{Mn}-(\mathrm{B})$ alloys were melted by using highpurity $\mathrm{Mg}, \mathrm{Zn}, \mathrm{Y}, \mathrm{Mn}$ and $\mathrm{Mg}-10 \mathrm{wt} \% \mathrm{~B}$ master alloy in an electric resistance furnace under the protective atmosphere of Ar gas at $1023 \mathrm{~K}$. Then, they were cast into a preheated mold at $993 \mathrm{~K}$. The solution treating at $773 \mathrm{~K}$ was implemented in a SX2-8-10 box type high-temperature electric resistance furnace, followed by water quenching. Phase constitution analysis was performed with Y-2000 X-ray diffraction (XRD) with monochromatic $\mathrm{Cu} K_{\alpha}$ radiation. The microstructures and compositions of different phases of the alloys were investigated by scanning electron microscopy (SEM, TESCANMIRA3) equipped to energy dispersive spectroscopy (EDS). The samples for tensile test were cut into rectangular with $4 \mathrm{~mm}$ in width, $2 \mathrm{~mm}$ in thickness and $40 \mathrm{~mm}$ in gauge length by an electric-sparking wire-cutting machine. Tensile testing was conducted on a DNS100 electronic universal material test machine at a crosshead speed of $0.2 \mathrm{~mm} / \mathrm{min}$ at room temperature. The size of $\mathrm{W}$-phase particles was determined by linear intercept method and image analysis technique.

\section{Results and Discussion}

\subsection{Microstructure Analysis}

It can be seen from Fig. 1 that after solid-solution treatment at $773 \mathrm{~K}$ for $40 \mathrm{~h}$, the eutectic phase with continuous network at the grain boundaries in the as-cast $\mathrm{Mg}-\mathrm{Zn}-\mathrm{Y}-\mathrm{Mn}-(\mathrm{B})$ alloys partially dissolved into $\mathrm{Mg}$ matrix and the remains transformed into particle phase. The XRD patterns (Fig. 2) and the EDS results (Fig. 3g, h) revealed that the particle phase was W-phase $\left(\mathrm{Mg}_{3} \mathrm{Zn}_{3} \mathrm{Y}_{2}\right)$ and the block phase in shape was $18 \mathrm{R}$ LPSO phase $\left(\mathrm{Mg}_{12} \mathrm{YZn}\right)$. As shown in Fig. 1c, d, the distribution of $\mathrm{W}$-phase in $\mathrm{Mg}_{94} \mathrm{Zn}_{2.5} \mathrm{Y}_{2.5} \mathrm{Mn}_{1}$ alloy containing $0.003 \mathrm{wt} \% \mathrm{~B}$ was more diffused with a higher degree of spheroidizing compared with $\mathrm{Mg}_{94} \mathrm{Zn}_{2.5} \mathrm{Y}_{2.5} \mathrm{Mn}_{1}$ alloy. The average diameter of the particles in $\mathrm{Mg}_{94} \mathrm{Zn}_{2.5} \mathrm{Y}_{2.5} \mathrm{Mn}_{1}$ alloy and $\mathrm{Mg}_{94} \mathrm{Zn}_{2.5} \mathrm{Y}_{2.5} \mathrm{Mn}_{1}$ alloy with $0.003 \mathrm{wt} \% \mathrm{~B}$ was 2.96 and $2.17 \mu \mathrm{m}$, respectively. This can be attributed to the addition of $\mathrm{B}$ which refined and reduced the volume fraction of W-phase in the as-cast alloy (Fig. 1a, b). In this case the refined $\mathrm{W}$-phase is more likely to be sphere and the particles' diameter becomes smaller during the heat treatment process. In addition, accompanied with the spheroidizing of $\mathrm{W}$-phase, the LPSO phase in $\mathrm{Mg}-\mathrm{Zn}-\mathrm{Y}-\mathrm{Mn}-(\mathrm{B})$ alloys partly dissolved into matrix during the heat treatment process.

Figure 3a-f showed the effect of solid-solution time on the morphology of W-phase in the $\mathrm{Mg}_{94} \mathrm{Zn}_{2.5} \mathrm{Y}_{2.5} \mathrm{Mn}_{1}$ alloy containing $0.003 \mathrm{wt} \%$ B. Obviously, the morphology of $\mathrm{W}$-phase at the grain boundaries gradually changed into strip-like and lump-like through diffusion and precipitation of alloying elements after solution treatment for $1 \mathrm{~h}$. With the increase in solid-solution time, the W-phase tended to be the break and sphere in shape, finally they were changed into irregular sphere. During the solid-solution time from
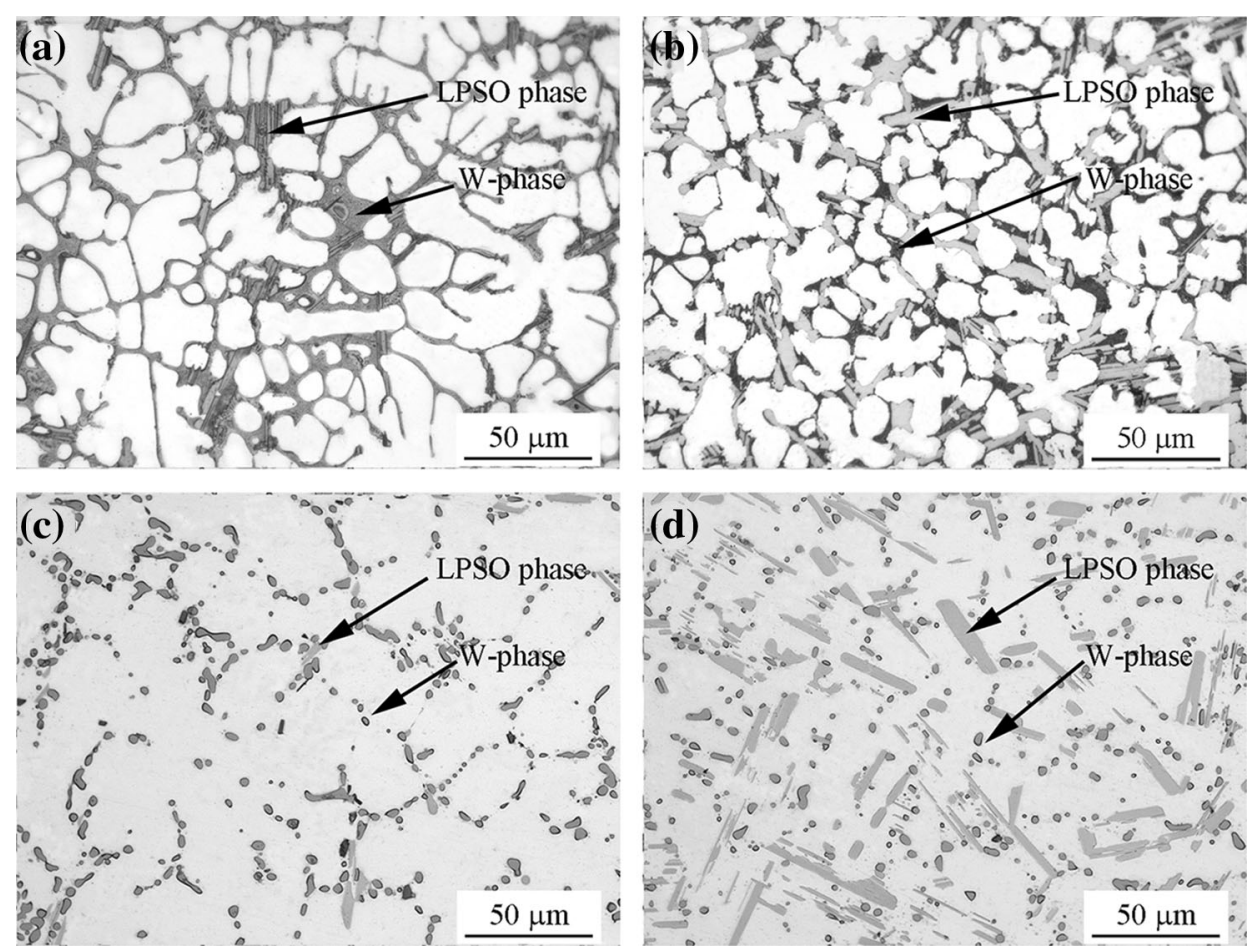

Fig. $1 \mathrm{OM}$ images of a as-cast $\mathrm{Mg}-\mathrm{Zn}-\mathrm{Y}-\mathrm{Mn}$ alloy; $\mathbf{b}$ as-cast $\mathrm{Mg}-\mathrm{Zn}-\mathrm{Y}-\mathrm{Mn}-\mathrm{B}$ alloy; $\mathbf{c}$ heat-treated $\mathrm{Mg}-\mathrm{Zn}-\mathrm{Y}-\mathrm{Mn}$ alloy; $\mathbf{d}$ heat-treated $\mathrm{Mg}-$ $\mathrm{Zn}-\mathrm{Y}-\mathrm{Mn}-\mathrm{B}$ alloy 


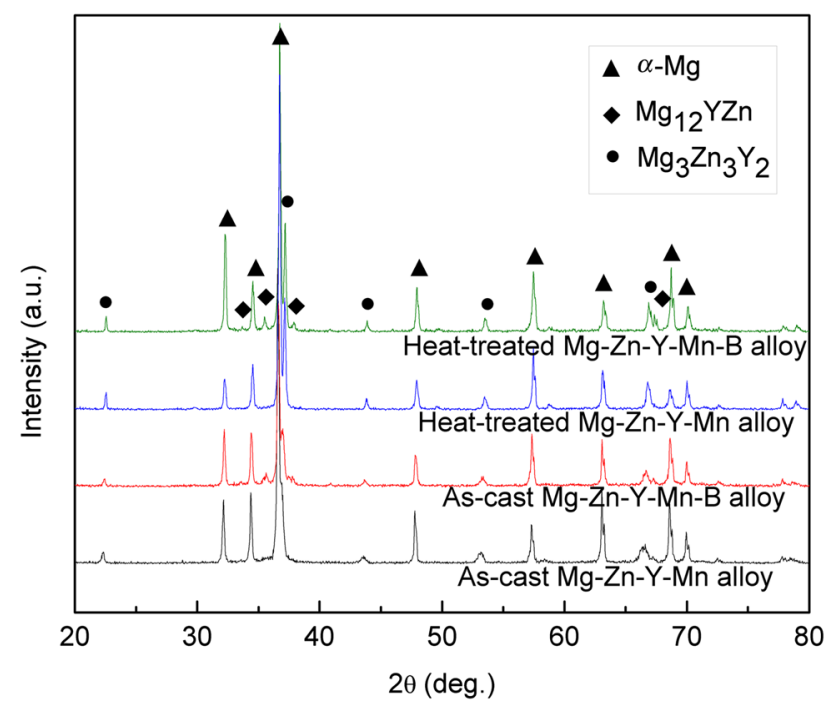

Fig. 2 XRD patterns of $\mathrm{Mg}-\mathrm{Zn}-\mathrm{Y}-\mathrm{Mn}-(\mathrm{B})$ alloys in different stages

20 to $40 \mathrm{~h}$, the morphology of $\mathrm{W}$-phase barely changed; however, the degree of spheroidizing became higher and the distribution of W-phase became more disperse, especially in $40 \mathrm{~h}$ (Fig. 3f). After solid-solution treatment for $55 \mathrm{~h}$, almost all W-phase particles were coarser than that of for $40 \mathrm{~h}$. Based on the OM and SEM observations, the schematic model shown in Fig. 4 was proposed to describe the W-phase evolution in the as-cast $\mathrm{Mg}-\mathrm{Zn}-\mathrm{Y}-\mathrm{Mn}-$ (B) alloys during solid-solution treatment process. In order to make the process easy to be understood,the network W-phase was simplified into a flake structure in the schematic diagram. This process can be mainly divided into three stages: (1) the flake W-phase becomes coarse, (2) the coarsened and irregular W-phase tends to be a sphere in shape, (3) the small W-phase particles dissolve and large ones grow up.

\subsection{Kinetics of Spheroidizing of W-phase}

According to the Thomson-Freundlich theory, the equilibrium solubility of alloy elements in the matrix is as follows:

$\ln \frac{(X a B)_{r}}{(X a B)_{\infty}}=\frac{2 \sigma M}{r R T \rho}$.

where $\sigma$ is surface tension; $M$ is relative atomic mass; $r$ is the particle radius; $\rho$ is the density; $(X a B)_{r}$ is solubility of $B$ in $a$ phase with radius of $r ;(X a B)_{\infty}$ is solubility of $B$ in $a$ phase with radius of $\infty$. Obviously, the smaller the curvature radius of the $\mathrm{W}$-phase is, the higher the elements concentrations in the vicinity of it are. As shown in Fig. 4, the concentrations of $\mathrm{Y}$ and $\mathrm{Zn}$ atoms in position $\mathrm{A}$ (smaller curvature radius) are higher than that in position $\mathrm{B}$ (larger curvature radius), where the concentration difference formed. Therefore, the $\mathrm{Y}$ and $\mathrm{Zn}$ atoms in the $\mathrm{W}$-phase could diffuse from position A to position B. This diffusion behavior destroys the interfacial equilibrium. As a result, the $\mathrm{W}$-phase in position $\mathrm{A}_{1}$ continuously dissolves and alloy elements diffuse and precipitate to position $B_{1}$. In this way the W-phase is coarsening (Fig. 4a) and sphering (Fig. 4b) and globular particles are growing up (Fig. 4c). In addition, the diffusion coefficient of $\mathrm{Y}$ in $\mathrm{Mg}$ matrix phase is lower than that of $\mathrm{Zn}$ by about one order of magnitude [12]. And such a slow diffusion speed of $\mathrm{Y}$ in $\mathrm{Mg}$ matrix phase can control the precipitation behavior of Y-containing $\mathrm{W}$-phase. So, the rate of this process is dominated by the diffusion of $\mathrm{Y}$ atoms.

\subsection{Mechanical Properties Analysis}

Tensile stress-strain curves of $\mathrm{Mg}-\mathrm{Zn}-\mathrm{Y}-\mathrm{Mn}-(\mathrm{B})$ alloys in different stages are shown in Fig. 5. It showed that the solid-solution treatment can affect the mechanical properties of the alloys significantly. After solid-solution treatment for $40 \mathrm{~h}$, the ultimate tensile strength, yield strength and ductility of the $\mathrm{Mg}_{94} \mathrm{Zn}_{2.5} \mathrm{Y}_{2.5} \mathrm{Mn}_{1}$ alloy were 225.1, 104.5 MPa and 14.9\%, respectively, whilst the $\mathrm{Mg}_{94}$ $\mathrm{Zn}_{2.5} \mathrm{Y}_{2.5} \mathrm{Mn}_{1}$ alloy containing $0.003 \mathrm{wt} \% \mathrm{~B}$ exhibited more desired properties with the values of 287.7, 125.5 MPa and $21.1 \%$, respectively. The increase in the strength and elongation after solid-solution treatment can be possibly attributed to the following aspects. First, after solid-solution treatment the morphology of W-phase changed from the network to the globular structure where the sharp corners did not exist anymore, avoiding stress concentration. And the globular phases played a slight role in hindering the dislocation movement, thus leading to a better elongation. Second, the concentrations of $\mathrm{Zn}$ and $\mathrm{Y}$ atoms in the Mg matrix phase largely increased with solidsolution time by the dissolution of LPSO phase and $\mathrm{W}$-phase as shown in Fig. 6. As recently reported, solute $\mathrm{Zn}$ and $\mathrm{Y}$ atoms induced far stronger solid-solution strengthening than other elements $[13,14]$. Therefore, the increases of $\mathrm{Zn}$ and $\mathrm{Y}$ concentrations significantly lead to an increase in ultimate tensile strength. Finally, the W-phase distributed in $\mathrm{Mg}_{94} \mathrm{Zn}_{2.5} \mathrm{Y}_{2.5} \mathrm{Mn}_{1}$ alloy containing $0.003 \mathrm{wt} \% \mathrm{~B}$ has been found to be more dispersive with a higher degree of spheroidizing and a smaller average diameter as compared to that of $\mathrm{Mg}_{94} \mathrm{Zn}_{2.5} \mathrm{Y}_{2.5} \mathrm{Mn}_{1}$ alloy.

\section{Conclusions}

The spheroidization process of $\mathrm{W}$-phase in the $\mathrm{Mg}-\mathrm{Zn}-\mathrm{Y}-$ $\mathrm{Mn}-(\mathrm{B})$ alloys consists of coarsening of flake W-phase, the spheroidizing of $\mathrm{W}$-phase and the growth of globular $\mathrm{W}$-phase. The W-phase distributed in $\mathrm{Mg}_{94} \mathrm{Zn}_{2.5} \mathrm{Y}_{2.5} \mathrm{Mn}_{1}$ 

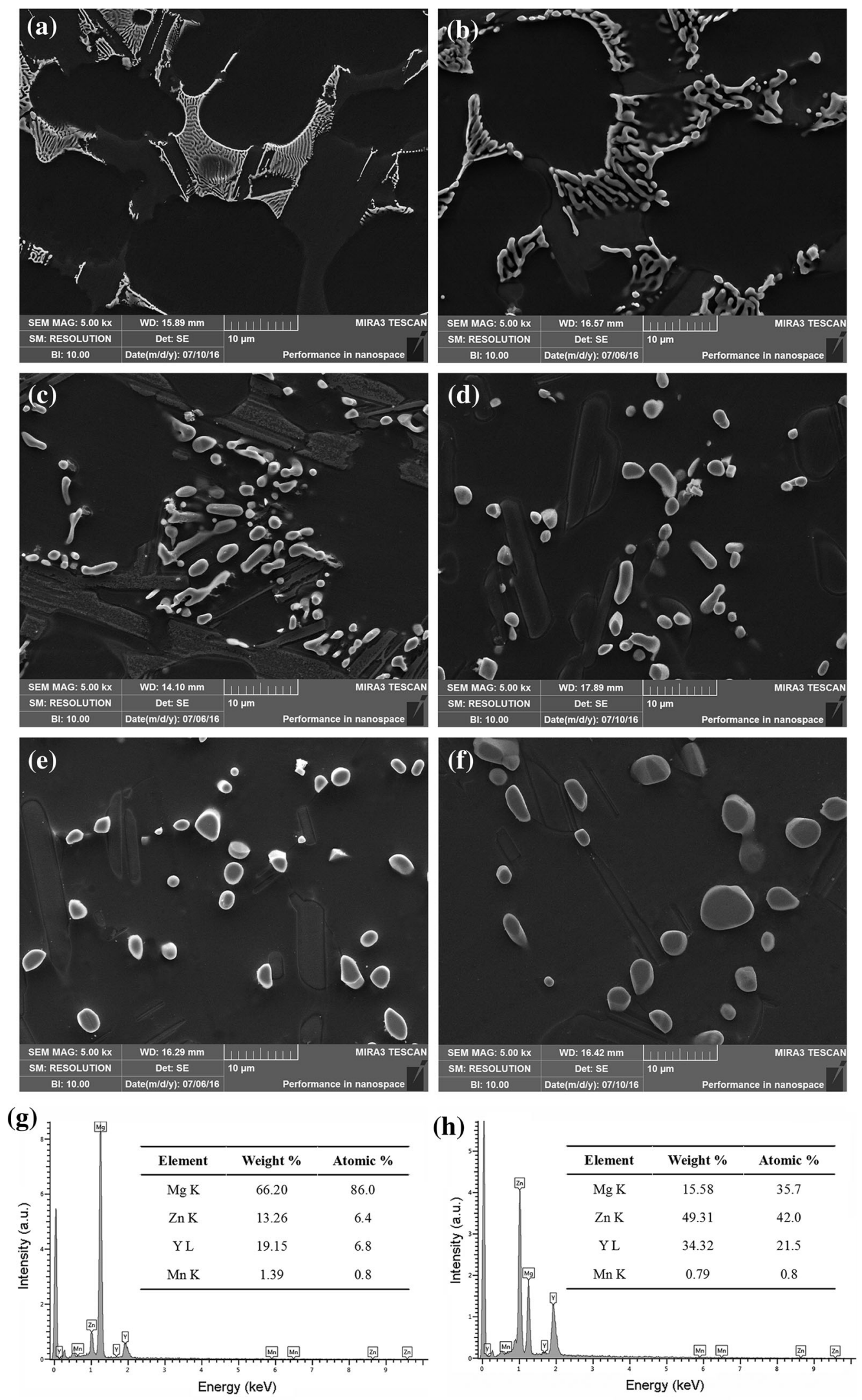

Fig. 3 SEM images of the as-cast Mg-Zn-Y-Mn-B alloy after solid-solution treatment at $773 \mathrm{~K}$ for different hours a $0 \mathrm{~h}$; b $1 \mathrm{~h}$; c $5 \mathrm{~h}$; d $20 \mathrm{~h}$; e $40 \mathrm{~h}$; $\mathbf{f} 55 \mathrm{~h}$, EDS spectra of $\mathbf{g}$ second phase $\mathbf{h}$ eutectic structures in heat-treated $\mathrm{Mg}-\mathrm{Zn}-\mathrm{Y}-\mathrm{Mn}-\mathrm{B}$ alloy 


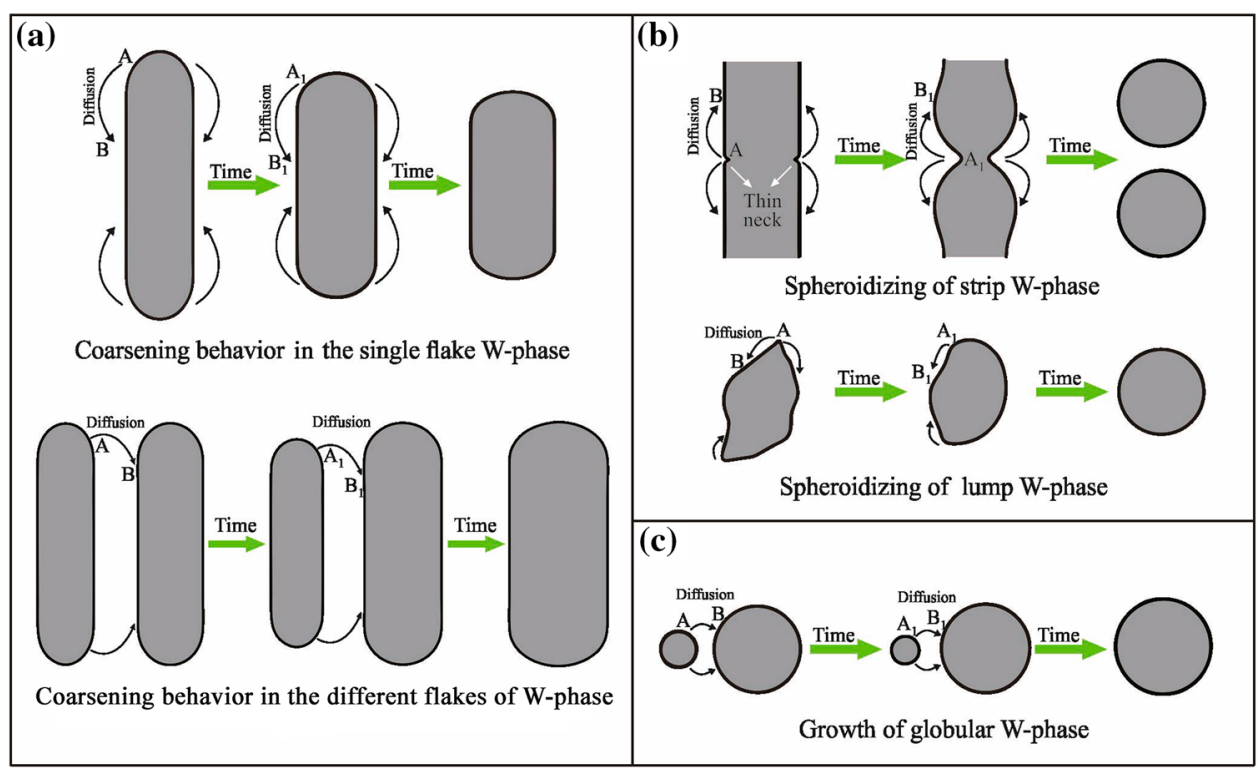

Fig. 4 Schematic presentation of the W-phase evolution during solid-solution treatment a coarsening of flake W-phase, b spheroidizing of W-phase, $\mathbf{c}$ growth of globular W-phase

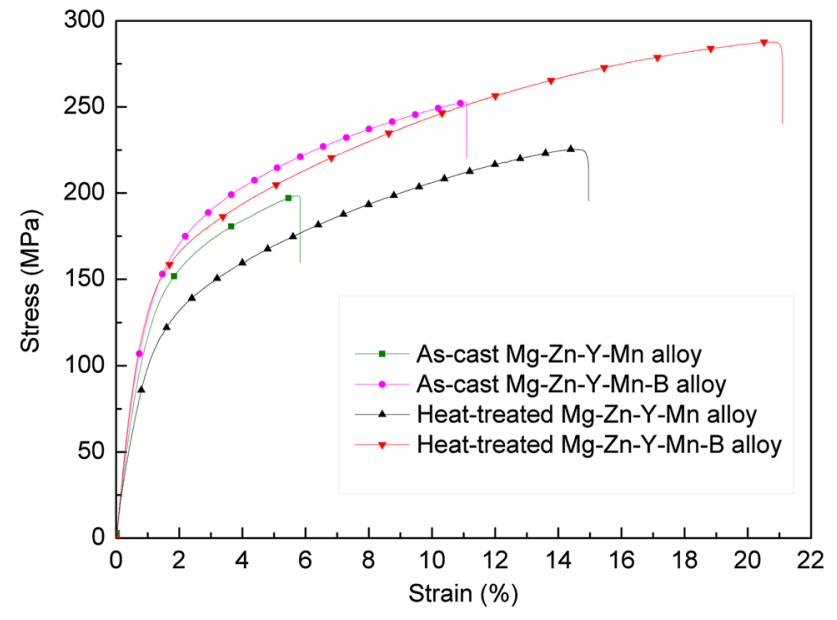

Fig. 5 Tensile stress-strain curves of $\mathrm{Mg}-\mathrm{Zn}-\mathrm{Y}-\mathrm{Mn}-(\mathrm{B})$ alloys in different stages

alloy containing $0.003 \mathrm{wt} \% \mathrm{~B}$ was found to be more dispersive with a higher degree of spheroidizing and a smaller average diameter as compared to that of $\mathrm{Mg}_{94} \mathrm{Zn}_{2.5} \mathrm{Y}_{2.5} \mathrm{Mn}_{1}$ alloy. The globular W-phase and solid-solution strengthening contribute to better mechanical properties for the $\mathrm{Mg}-\mathrm{Zn}-\mathrm{Y}-\mathrm{Mn}-(\mathrm{B})$ alloys. After solid-solution treatment at $773 \mathrm{~K}$ for $40 \mathrm{~h}$, the ultimate tensile strength, yield strength and ductility of $\mathrm{Mg}_{94} \mathrm{Zn}_{2.5} \mathrm{Y}_{2.5} \mathrm{Mn}_{1}$ alloy containing $0.003 \mathrm{wt} \% \mathrm{~B}$ reached $287.7,125.5 \mathrm{MPa}$ and $21.1 \%$, respectively.

Acknowledgements The authors acknowledge the financial support from the National Natural Science Foundation of China (Nos. 51474153 and 51574175), Ph.D. Programs Foundation of Ministry of Education of the People's Republic of China (No. 20111402110004) and Natural

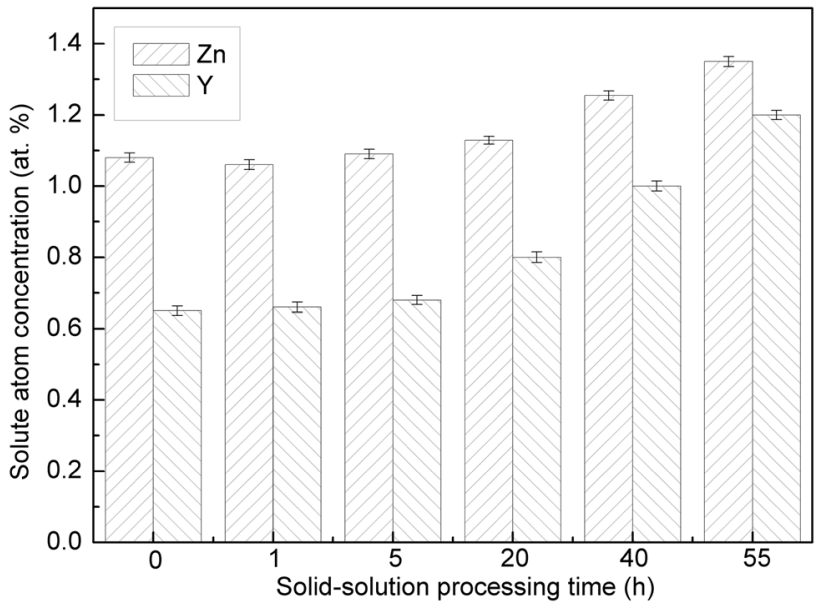

Fig. 6 Concentrations of $\mathrm{Zn}$ and $\mathrm{Y}$ in $\mathrm{Mg}$ matrix phase at different solid-solution time in $\mathrm{Mg}-\mathrm{Zn}-\mathrm{Y}-\mathrm{Mn}-\mathrm{B}$ alloy, as measured by the SEM-EDS method

Science Foundation of Shanxi Province (Nos. 2009011028-3 and 2012011022-1).

\section{References}

[1] S. Shao, Y. Lin, C.S. Xu, Y.X. Xu, B. Wu, X.S. Zeng, X.F. Lu, X.J. Yang, Acta Metall. Sin. (Engl. Lett.) 28, 7 (2015)

[2] D.Q. Wan, G.C. Yang, M. Zhu, Acta Metall. Sin. (Engl. Lett.) 20, 429 (2007)

[3] Z.M. Zhang, C.J. Xu, X.F. Guo, Acta Metall. Sin. (Engl. Lett.) 21, 37 (2008)

[4] E. Oñorbe, G. Garcé, P. Pérez, S. Cabezas, M. Klaus, C. Genzel, E. Frutos, P. Adeva, Scr. Mater. 65, 719 (2011)

[5] J.Y. Lee, D.H. Kim, H.K. Lim, D.H. Kim, Mater. Lett. 59, 3801 (2005) 
[6] Y.B. Xu, D.K. Xu, X.H. Shao, E.H. Han, Acta Metall. Sin. (Engl. Lett.) 26, 217 (2013)

[7] D.K. Xu, L. Liu, Y.B. Xu, E.H. Han, Mater. Sci. Eng. A 443, 248 (2007)

[8] J. Wang, J.S. Zhang, X.M. Zong, C.X. Xu, Z.Y. You, K.B. Nie, Mater. Sci. Eng. A 648, 37 (2015)

[9] P.H. Fu, L.M. Peng, H.Y. Jiang, J.W. Chang, Mater. Sci. Eng. A 486, 183 (2008)

[10] S.Q. Feng, W.Y. Zhang, Y.H. Zhang, J.Y. Guan, Y.C. Xu, Mater. Sci. Eng. A 609, 283 (2014)
[11] K. Yang, J.S. Zhang, X.M. Zong, W.X. Wang, C.X. Xu, W.L. Cheng, K.B. Nie, Mater. Sci. Eng. A 669, 340 (2016)

[12] S.K. Das, Y.B. Kang, T.K. Ha, I.H. Jung, Acta Mater. 71, 164 (2014)

[13] A.H. Blake, C.H. Cáceres, Mater. Sci. Eng. A 483-484, 161 (2008)

[14] L. Gao, R.S. Chen, E.H. Han, J. Alloys. Compd. 472, 234 (2009) 